\title{
Magtesløshedens politik
}

\section{Mads Qvortrup}

Irlands nej til Lissabontraktaten har rejst mange problemer og udfordringer for EU's stats- og regeringsledere, men krigen i Georgien og forholdet til Rusland har vist, at Fællesskabet har brug for andet og mere end blot institutionelle reformer. En vedtagelse af Lissabontraktaten er næppe nok

Det har været nogle bevægende måneder for EU - i det store som i det små.

Unionen blev kastet ud i en næsten eksistentiel krise, da 53 procent af de irske vælgere sagde nil (som nej hedder på gælisk) til Lissabontraktaten.

Men det var ikke det eneste område, der viste skrøbeligheden af unionen.

Flere afgørelser fra EU-domstolen - blandt andet om dansk udlændingepolitik - viste, at nationalpolitik ikke lader sig samordne med nationale politiske præferencer. Og så var der endelig uenigheden om forholdet til Rusland.

De forskellige sager bliver sjældent set som del af en helhed, men de peger alle på de underliggende problemer som stats- og regeringschefer står overfor - og som de får svært ved at løse ad institutionel vej.

"Kongressen danser, men den bevæger sig ikke." Sådan sagde Fürst Metternich, den østrigske diplomat om Wienerkongressen, hvor Europas stormagter og småstater forsøgte at finde en løsning på kontinentets rivaliserende stormagtsambitioner dengang efter Napoleonskrigene.

Der var mindre morskab i Bruxelles i september 2008 end i Wien i årene 1814-1815. Men problemstillingen var den samme, da EU's førstemænd mødtes til et ekstraordinært topmøde og prøvede at finde en ordning på den sikkerhedspolitiske situation, der er opstået i kølvandet på krigen i Georgien.

Man kan undre sig over, at vi på 
dette sted benytter en krig i Europas randområde til at analysere Unionens fremtid.

Krisen i Georgien var - og er i skrivende stund - blot et af mange politiske problemer, som EU slås med, men den har - som sådant ikke noget at gøre med Fallesskabets forfatningsmæssige arkitektur.

Intet kunne være mere forkert. For det er netop denne manglende evne til at samtænke de overordnede problemstillinger og udfordringer, som er en af grundene til EU's krise. I det spil kommer det irske nej ved folkeafstemningen $i$ juni i anden række, omend det ikke er uvæsentligt.

Afstemningen viste, at det ene land, der fik lov til at stemme om traktaten - det land hvor EU er mest populært (ifølge Eurobarometer) stemte nej. Et tilsvarende resultat ville have været sandsynligt $i$ andre lande. Men at selv de såkaldte eliter er uenige, er ligeså problematisk, selv om det ofte overses.

Det er derfor, der er grund til at se nærmere på topmødet som et slags case study.

\section{Bruxelles september 2008}

De 27 medlemslande mødtes andægtigt, men resultatet var, høfligt sagt, intetsigende. EU's partnerskabsaftale er lagt på is. Topmødets slutdokument sagde, at "Forholdet mellem EU og Rusland er ved en skillevej. Der er spørgsmål der må rejses”.
Det tog de ikke megen notits af i Moskva. Det er EU, der har behov for russernes olie og naturgas. Dmitrij Medvedev, Vladimir Putin og Gazprom kan finde andre kunder til oliebutikken, der ikke stiller irriterende spørgsmål om udenrigspolitik og menneskerettigheder - som for eksempel Folkerepublikken Kina et land, der som bekendt ni ud af ti gange stemmer sammen med Rusland i FN's Sikkerhedsråd.

Så udtalelsen betyder ikke meget, og får næppe praktisk endsige symbolsk betydning. Topmødeudtalelsen betyder i bedste fald, at EU's stats- og regeringschefer har sagt $f y$, fy skamme til Rusland. Dermed har de kun vist Unionens magtesløshed.

Det er EU's udenrigspolitiske problem i en nøddeskal, at den imponerende institutionelle arkitektur ikke kan omsættes i politisk vilje og slet ikke i handling. Så lad os for en stund gå tilbage til den forkastede traktat og indholdet af den samt hvorfor det er relevant.

\section{EU's handlingslammelse}

Mange var skuffede, da de irske vælgere stemte nej til en traktat, der ville have givet EU en de facto udenrigsminister. Men spørgsmålet er, hvad EU overhovedet skal med en udenrigsminister - for slet ikke at nævne en præsident - hvis man ikke kan blive enige om noget så relativt enkelt som en fælles holdning til Ruslands ekspansive udenrigspolitik. 


\section{MADS QVORTRUP}

Ved at udstille ikke blot deres magtesløshed, men også deres uenighed, har topmødet ikke blot undergravet stats- og regeringschefernes diplomatiske position, men også vist, at Europa spiller en birolle i konflikten i Georgien, mens USA spiller en langt større rolle.

For så vidt er situationen ikke meget anderledes end i 1990'erne, hvor EU var tavse vidner til folkemordet i Bosnien-Hercegovina, og hvor den Europæiske Union var magtesløs over for (primært) serbiske overgreb mod primært muslimske befolkningsgrupper.

Dengang i 1990'erne måtte der amerikansk indgriben til for at sikre, at freden blev genoprettet og krigen sluttet. Det samme var tilfældet i 1999, da Europa spillede en begrænset rolle i forbindelse med konflikten i Kosovo. Her måtte USA for anden gang gribe ind, mens EU spillede en begrænset birolle som heppekor og med symbolske britiske bidrag til amerikanske bombetogter over Beograd.

Det var denne pinlige situation, der var en af grundene til, at EUlandene inkorporerede ideen om en fælles udenrigsminister og en fælles præsident.

Med nye institutioner skulle det gøres muligt for Fællesskabet at være mere handlekraftigt over for fremtidige kritiske situationer både på det europæiske kontinent og ude i den vide verden.

Man hævdede, at disse institutio- nelle nydannelser var endnu mere påkrævede på et tidspunkt, hvor den Europæiske Union bestod af ikke seks, ikke tolv, men syvogtyve medlemmer. Stemmevægtene måtte revideres således, at det blev lettere at foretage beslutninger.

Der kan være grund til at se nærmere på spørgsmålet om stemmevægte - om ikke andet så for at blive erindret om, hvor byzantinske reglerne er.

Ifølge den gældende Nicetraktat skal der i Rådet, hvis det skal mønstre et såkaldt kvalificeret eller dobbelt flertal, sikres opbakning fra 258 ud af 345 stemmer (dvs. 74 procent af medlemslandene). Dette flertal skal ydermere repræsentere 62 procent af EU's borgere.

Det kvalificerede flertal er den primære måde at træffe beslutninger på, hvis der ikke kan skabes konsensus. De fire indbyggermæssigt største lande Tyskland, Storbritannien, Frankrig og Italien har 29 stemmer, mens Spanien og Polen har 27 stemmer.

Forfatningstraktaten, som blev forkastet af Frankrig og Holland (men vedtaget ved folkeafstemninger i Spanien og Luxembourg), foreslog 55 procent af medlemslandene samt 65 procent af befolkningen. Denne model blev foreslået, fordi den i højere grad reflekterer størrelsen på befolkningerne og sætter skub i de større landes magt. Det var især populært i Tyskland og Storbritannien, men blev en anstødssten i 
Polen, hvor præsidenten endnu ikke har underskrevet traktaten, selvom den er blevet ratificeret i parlamentet.

Efter folkeafstemningerne i 2005 blev emnet genåbnet, og medlemslandende nåede trods modvilje fra de større lande (især Tyskland) frem til et kompromis. Ifølge dette vil de nuværende stemmeregler fra Nicetraktaten gælde frem til 2014.

I en overgangsperiode frem til 2017 vil de nye regler om 55 procent af medlemslandene og 65 procent af befolkningen være gældende, men stemmevægtene fra Nicetraktaten kan tages i brug i stedet, hvis et medlemsland ønsker det. Og det er endda kun den forsimplede udgave. Måske er det grund til at gå op til et højere teoretisk niveau. For dette handler ikke så meget om esoteriske stemmeregler, som det handler om politik.

\section{Charles de Gaulle}

Une constitution, $c$ est un esprit, des institutions, une pratique. "En forfatning er dens ånd, dens institutioner og den praktiske brug”. Sådan, lettere frit oversat, sagde den franske præsident Charles de Gaulle på en pressekonference i 1964.

Dette er ikke stedet, endsige tidspunktet, til at diskutere om Lissabontraktaten er en forfatning. Diskussionen om, hvorvidt Forfatningstraktaten, som blev nedstemt af franskmænd og hollændere i 2005, er identisk med - eller forskellig fra - den traktat, som et flertal af de irske vælgere forkastede i 2008, er mere udtryk for en politisk vurdering end den er udtryk for juridisk sagkundskab. Men hvad man end mener om sagen, så er Lissabontraktaten et dokument, der indfører nye politiske institutioner - og dermed har traktaten (ligesom Rom-, Maastricht og Amsterdam-traktaten) en forfatningsmæssig karakter. Alle disse traktater indfører en magtdeling mellem institutioner og begrænsninger i magtudøvelsen. En forfatning er et sæt af regler, der opdeler regler, rettigheder og institutionelle beføjelser.

Ud fra en neutral definition er Lissabontraktaten dermed en forfatning.

Det er ikke ment kontroversielt, men rent definitorisk. Og det er her Charles de Gaulles observation kommer ind.

Den store franske statsmand vidste, hvad hans nuværende kollegaer ikke synes at være opmærksomme på, nemlig dette, at en forfatning eller et politisk system - ikke blot er resultatet af regler og institutioner, men også et resultat af holdninger, følelser og det, som franske forfatningsteoretikere med et ord hentet fra filosoffen Alexis de Tocqueville kalder mœurs og som vi kan oversætte til vaner, kultur og følelser i bredeste forstand.

Den Femte Republiks forfatning, som de Gaulle skrev og fik gennem- 
ført i slutningen af 1950'erne, var ikke bare et system, der indførte et præsidentielt styre, et forfatningsråd og andre ændringer. Det franske politiske system blev ikke kun ændret ved, at der blevet lavet om på forfatningens bogstav. De var også et resultat af, at der blev lavet om på forfatningens ånd - dens esprit.

De stridigheder og den opfattelse af politik, der eksisterede under den Fjerde Republik i 1950'erne (hvor Frankrig var uregerlig og havde mange kortlivede regeringer) blev ændret ved, at der opstod en ny ånd, men også en ny practique - en ny forfatningspraksis. Men det var kun fordi der eksisterede un esprit, en fælles kultur, som de Gaulle og hans ministre kunne henvise til, at dette politiske system havde succes.

Dette er også problemet for EU som politisk projekt. Det er ikke institutioner, EU mangler, men en fælles forfatningsånd og en fælles opfattelse af, hvad der er den bærende ide. Politiske institutioner er kun en lille delmængde af en forfatning.

Og det er derfor topmødet i Bruxelles er så væsentligt. For den minimalistiske sluterklæring viser, at der nok eksisterer et fælles set af spilleregler, men der mangler et fælles set af mœurs - af kulturelle vaner og politisk kultur - og ikke mindst en fælles esprit.

\section{Hinsides Irland}

Afstemningen i Irland har ført til mange overvejelser om, hvordan Europa kommer videre. Den irske regering har iværksat en undersøgelse af, hvilke faktorer der lå bag vælgernes dom over Lissabontraktaten. Selv den franske præsident Nicolas Sarkozy tog til Irland i juli og lyttede til hver af modstanderorganisationerne. De fik tre minutter hver! At Sarkozys besøg ikke blev opfattet som hjælpsomt af den irske premierminister Brian Cowen, er der ikke grund til at dvæle ved, men det siger måske en del om den gensidige politiske forståelse landene imellem eller rettere sagt mangel på samme.

Selvom den irske regering siger, at det endnu er for tidligt at diskutere en ny folkeafstemning - en afstemning, der er påkrævet i henhold til landets forfatning - tegner der sig allerede nu konturerne af et kompromis.

Ifølge dette vil de små lande få lov til at beholde deres kommissærer. Der vil angiveligt også blive indført en protokol, som bekræfter, at Lissabontraktaten ikke får indflydelse på irsk neutralitetspolitik og på landets (meget) restriktive abortregler i et land, der to gange har afvist at indføre kvinders ret til at vælge svangerskabsafbrydelse.

Ikke alle i Irland er begejstrede herover. Declan Ganley, den excentriske millionær, som brugte over en million euro på at føre kampagne imod Lissabontraktaten, har afvist at gå på kompromis. Han er ikke alene om denne kompromisløse hold- 
ning. Men der er kommet mildere toner fra oppositionspartiet Sinn Fein. Partiet vil gerne i regering, og hvis de kan sammensmede et kompromis vil de have vist deres regeringsduelighed.

Så selvom meningsmålinger i skrivende stund (august 2008) tyder på, at der er endnu større modstand mod Lissabontraktaten end i juni, er det ikke umuligt, at en protokol kan vinde tilslutning fra vælgerne - lidt på samme måde som danskerne ombestemte sig og stemte $j a$ til Edinburgh-kompromiset i 1993, efter de i 1992 havde stemt nej til Maastrichttraktaten.

Men denne løsning er langt fra ideel. Nogle vil hævde, at selv denne udvej er problematisk, fordi valget til Europa-Parlamentet næste år skal foregå efter de nye regler. Men det er - selvom det er alvorligt nok kun et administrativt problem. Men den slags kan løses af kreative embedsmænd, og dem er der ikke mangel på i EU-systemet.

Men alt dette løser ikke det helt fundamentale problem. Og dette er, at en forfatning ikke kun er institutioner, men også de føromtalte holdninger og følelser, kort sagt; ånd, institutioner og praktisk brug, for igen at henvise til Charles de Gaulle.

Og to af disse - ånd og praksis eksisterer ikke. Selvom EU havde vedtaget de nye regler, og endda bedre institutioner, ville der ikke være blevet opnået enighed om en mere manifest holdning over for
Rusland, hvis det da havde været ønskværdigt. For EU-landene er ikke enige. Sovjetunionens gamle nabolande er skeptiske over for Moskva, mens landene i Vesteuropa og især Tyskland er mere milde over for den store og olierige nabo i øst. En sådan uenighed er ikke forenelig med en politisk union. Man kunne ikke tænke sig en tilsvarende uenighed mellem for eksempel amerikanske delstater.

\section{Jean-Jacques Rousseau}

Kan der gøres noget ved det? Det er i hvert fald ikke noget nyt problem i den politiske tænknings historie. Faktisk er det et emne, der har optaget filosoffer og andre teoretikere i adskillige hundrede år.

For tohundrede år siden - i nationalstatens spædeste barndom - foreslog den fransksprogede schweiziske filosof Jean-Jacques Rousseau (der dengang var specialkonsulent for den polske regering) sine arbejdsgivere i Warszawa, at de ikke bare skrev en forfatning, men at de også måtte udvikle en fælles ånd. For kun hvis man etablerede en fælles kultur og sikrere sig, at en sådan havde mulighed for at gro, kunne man gradvist nå frem til en politisk kultur, der kunne sikre landets uafhængighed og frihed, som Rousseau skrev i værket Considerations Sur Le Gouvernement De Pologne - eller "Overvejelser over Polens Forfatning”. Rousseau foreslog, at polak- 


\section{MADS QVORTRUP}

kerne lærte af spanierne og brugte sport til at skabe sammenhold. "Hvad ville spanierne være uden tyrefægtning”, spurgte filosoffen retorisk. Han påpegede dermed, at intet politisk fællesskab kan etableres eller opretholdes uden en fælles kultur og et åndeligt fællesskab.

Man kan selvsagt ikke sammenligne Polen i det 18. århundrede med hele Europa i det 21. århundrede, men der er nogle af de samme problemer. De er blot værre i tilfældet Europa. For mens polakkerne trods alle deres forskelligheder havde en fælles religion og et nogenlunde fælles sprog, er ingen af de to ting tilfældet i Europa som helhed.

Europa er et kludetæppe af forskelligheder. Det gør det umuligt at appellere til fælles myter og en fælles fortid. Og det er ikke muligt, at skabe en fælles europæisk nationalsport på samme måde som Rousseau forestillede sig i 1771.

Hele denne lange udredning kan virke filosofisk - og dermed verdensfjern - for mange almindelige læsere, især for praktisk orienterede politikere, der ønsker handling frem for langhåret teori og analyse. En sådan indstilling er forståelig, men ikke dermed rigtig. For i denne situation er sagen den, at de europæiske lande mangler et fælles grundlag.

At finde dette er den store ubekendte, den cirklens kvadratur, som ingen form for variabel geometri har kunnet løse. Hvis ikke der fin- des en form for fælles grundlag, er det de europæiske landes skæbne at være småstater i randområdet til Rusland.

\section{Magtpolitik}

Henry Kissinger beklagede sig engang over, at man ikke kunne ringe til et enkelt telefonnummer, hvis man ville tale med Europa. Svaret på dette problem er ikke at oprette et telefonabonnement i Bruxelles for den nye fælles udenrigsminister, men at skabe grundlag for en fælles holdning.

Denne har som nævnt manglet ved topmødet. Hvad er alternativerne da? Måske, at EU bestræber sig på noget mindre og løsere. For det er i realiteten blevet konsekvensen. Tiden er løbet fra EU i den form, som det var tiltænkt af Romtraktatens forfattere. Vi er i realiteten tilbage ved det nationernes Europa, som de Gaulle advokerede.

Charles de Gaulles arvtager, Frankrigs præsident Nicolas Sarkozy, havde en vis moderat succes med sit mæglingsforsøg i begyndelsen af konflikten. Men da han blandede hele EU ind i problematikken, svandt troværdigheden ind. For pludselig skulle der findes enighed. Og man kunne end ikke blive enige om, hvem der havde ansvaret for krigen.

Frankrig kunne spille rollen som mægler, fordi det ikke var part i konflikten. Det kan EU ikke af den 
grund, at mange medlemslande er fjendtligt indstillede over for Rusland. Det samme kan andre lande, men kun hver for sig.

En koalition kan kun bestå, hvis der er et minimum af enighed og interesser. Efter EU's udvidelse mod øst er Unionen blevet så stor, at man ikke kan opnå enighed. Og dette vil ikke blive ændret, selvom Lissabontraktaten bliver vedtaget. Institutioner er meningsløse uden politisk enighed.

Reaktionen over for den russiske invasion af Georgien har dermed banket endnu et søm i den politiske unions ligkiste og vist, at det er en fiktion at tale om en fælles europæisk holdning i sikkerhedspolitikken.

Det er en tragedie hvis man ser det som et politisk mål, at EU udgør en stor og sikkerhedspolitisk modvægt til USA, Rusland og Kina. Dette mål giver kun mening, hvis man ved, hvad EU vil. Og det ved EU ikke. Alle landene ønsker, at Europa skal være en modvægt, men indholdet af denne politik er altid, at Fællesskabet skal føre fransk, tysk eller engelsk udenrigspolitik. Og da disse er forskellige, er der ikke mulighed for at skabe resultater i praksis.

Winston Churchill sagde engang lettere hånligt, at "Indien ikke er et land, men et geografisk begreb lidt ligesom ækvator". Noget af det samme kunne siges om EU. De næste måneders udvikling vil angiveligt føre til en form for institutionelt kompromis. Men det vil ikke ændre afgørende på EU's handlekraft og politiske betydning. Institutioner er kun rammer og er i sig selv betydningsløse, hvis de ikke hviler på et fælles politisk grundlag, på en fælles ånd.

Mads Qvortrup er professor i statskundskab ved Robert Gordon University $i$ Skotland og udenrigspolitisk journalist på Information. 




